Gut, 1975, 16, 847-853

\title{
Peripheral blood and intestinal lymphocyte sub-populations in Crohn's disease ${ }^{1}$
}

\author{
R. G. STRICKLAND, GUNNAR HUSBY, W. C. BLACK, AND \\ RALPH C. WILLIAMS, JR \\ From the Division of Gastroenterology, Department of Medicine, University of New Mexico School of \\ Medicine, Albuquerque, New Mexico
}

SUMMARY Immunofluorescent techniques were utilized to study the nature and distribution of cells forming the inflammatory infiltrate in Crohn's disease. Tissue from resected ileum (one patient) or colon (one patient) when compared with corresponding control tissues contained increased numbers of B and T lymphocytes. B-cells of IgG class predominated in the mucosal lamina propria, whereas T-cells were prominent in the deeper layers of inflamed bowel. Inflammatory cells bearing Fc receptors were also present in these tissues. Decreased peripheral blood T-cell numbers returned to normal after resection of the involved bowel in the two patients studied. Impaired cellular immunity in Crohn's disease may thus result from T-cell sequestration in or loss from involved segments of intestine.

A number of studies relating to cell mediated immunity have been reported in patients with Crohn's disease. Several authors have recorded impaired cutaneous delayed hypersensitivity (Williams, 1965; Jones et al., 1969) and depressed in vitro peripheral blood lymphocyte responsiveness to non-specific mitogens such as phytohaemagglutinin (Parent et al., 1971; Guillou et al., 1973; Sachar et al., 1973) or in mixed lymphocyte culture (Richens et al., 1974). In addition, we have recently identified a quantitative depression of circulating thymus-derived $(T)$ lymphocytes in some patients with Crohn's disease (Strickland et al., 1974). However, other workers using similar techniques have reported contradictory results (Fletcher and Hinton, 1967; Röpke, 1972; Asquith et al., 1973; Bird and Britton, 1974; Bolton et al., 1974) and it is clear that a depression of T-cell function or circulating T-cell numbers is not universally present in patients with Crohn's disease.

In the course of our investigations of lymphocyte abnormalities in Crohn's disease we have recently studied two patients before and after intestinal resection. The present report records our observations of $\mathrm{T}$ and $\mathrm{B}$ lymphocyte distributions in both

${ }^{1}$ Supported by grants No. AMAI 13824-05 and AM13690-05 from the U.S. Public Health Service.

Received for publication 18 September 1975. peripheral blood and resected intestine from these patients.

\section{Methods \\ PATIENTS}

Patient CL is a 32 year old white female with a 10 year history of recurrent Crohn's disease. She had undergone a previous resection of $45 \mathrm{~cm}$ of terminal ileum and ascending colon in 1966, lysis of adhesions and bypass of $40 \mathrm{~cm}$ of recurrent ileal disease with ileotransverse colostomy in 1967, an anal fissurectomy and sphincterotomy in 1969, and repair of a rectovaginal fistula in 1973 . A $10 \mathrm{~cm}$ rectal stricture was identified in 1972. Because of persistent difficulty with defecation, recurrent partial large bowel obstruction and perirectal abscesses unresponsive to local and systemic corticosteroids and azulfidine, she underwent further surgery in 1975 . Resection of the excluded ileal segment, and an abdominoperineal resection with sigmoid colostomy were carried out. Her postoperative course was uneventful, the perineal wound healed normally and she now has a well-functioning colostomy. Pathological examination of the rectal stricture and excluded ileum revealed transmural chronic inflammation and fibrosis with granulomas and multiple fissuring mucosal ulcers. Sections of the proximal line of resection revealed normal colonic mucosa. 
Patient G.V. is a 15 year old white male with a five year history of recurrent Crohn's disease. He had undergone a previous resection of $90 \mathrm{~cm}$ of terminal ileum and ascending colon with ileotransverse colostomy in 1971. He remained well for a year but then developed recurrent ileal disease proximal to the anastomosis, requiring systemic corticosteroids for control of symptoms of abdominal pain, weight loss, fever, and diarrhoea. Continued need for corticosteroids led to growth failure over the next two years. In 1974 he developed a partial small bowel obstruction which responded initially to conservative measures but promptly recurred. At operation an $8 \mathrm{~cm}$ stricture of the ileum was found commencing at the line of anastomosis. A distal ileectomy and proximal colectomy with ileocolostomy were performed. The postoperative course was uneventful and the patient is now symptom free, is on no drug therapy, and has started to grow. Pathological examination of the resected specimen revealed mucosal ulceration, transmural chronic inflammation and fibrosis, and scattered giant cell granulomata. The lines of resection revealed normal ileal and colonic mucosa.

TISSUE IMMUNOHISTOCHEMICAL STUDIES Fresh tissue involved by Crohn's disease was obtained from the resected specimens of small (patient GV) and large (patient CL) intestine. Tissue samples of normal ileum and colon from two patients undergoing right hemicolectomy for colon carcinoma served as controls. A portion of each sample was embedded in Ames O.C.T. compound (Ames Company, Elkhart, Indiana) and quick-frozen in dry ice-acetone. Tissue samples were also washed by slow rotation in PBS for 24 hours at $4^{\circ} \mathrm{C}$ before freezing in order to remove diffusable proteins (Husby et al., 1973). Frozen sections (4 $\mu$ ) were cut, fixed in cold acetone for five to 10 minutes and thereafter stained with the various antisera described below, washed in PBS, and mounted. Immunofluorescent identification of tissue B- and T-cells followed methods which have been recently described in detail (Husby et al., 1975).

$B$-cells Tissue B-cells were detected using the fluoresceinated pepsin fragments of polyvalent rabbit IgG antibodies to human immunoglobulins (Ig). Cells with surface (rim) or cytoplasmic staining (B-lymphocytes and plasma cells) were regarded as belonging to the B-cell line. Rabbit antisera made specific for the Fc portion of human IgG, IgA, IgM, and IgE by passage through immunoabsorbent columns (Husby et al., 1973) were labelled with fluorescein isothiocyanate (FITC) and used to determine the relative Ig class distribution of tissue fixed B-cells. Aggregates of fluoresceinated IgG were used to detect cells bearing the Fc receptor. This method identifies cell types other than lymphocytes bearing the Fc receptor such as macrophages and polymorphonuclear granulocytes (Husby et al., 1975).

T-cells Tissue T-cells were detected by indirect immunofluorescence utilizing an extensively absorbed antiserum to isolated human thymocytes (Husby et al., 1975) and followed by a second layer of fluoresceinated goat anti-rabbit IgG. The anti-T-cell antiserum stained only the T-cell dependent areas of sections from normal human spleen and lymph nodes (Husby et al., 1975).

Several, high power microscopic fields of neighbouring sections stained for B- and T-cells respectively, were examined, and 200 fluorescent cells or more were enumerated in order to determine the proportions of B-and T-cells. An estimate of the degree of inflammatory cell infiltration in these areas was obtained by examination of adjacent sections stained with haematoxylin and eosin and examined by light microscopy.

PERIPHERAL BLOOD B AND T LYMPHOCYTE DETERMINATIONS

Lymphocytes were separated from heparinized venous blood by Ficoll-Hypaque gradient centrifugation at room temperature. Polyvalent rabbit IgG antibodies to human immunoglobulins were isolated by passage through a DEAE cellulose column and digested with pepsin (Husby et al., 1975). The resulting $F\left(a^{\prime}\right)_{2}$ fragments of the rabbit antibodies were then labelled with FITC and used in the direct immunofluorescence technique to detect B lymphocytes bearing Ig on their surface. The pepsin fragment of the rabbit antibodies was used to avoid staining of cells having the Fc receptor, but lacking surface Ig (Winchester et al., 1975). In some instances B-cells with Fc receptors were determined using aggregates of fluoresceinated IgG as described by Dickler and Kunkel, 1972. T-cells were enumerated using the sheep red cell rosette technique which employed sheep erythrocytes, initial incubation at $37^{\circ} \mathrm{C}$ for 30 minutes, followed by overnight incubation at $4^{\circ} \mathrm{C}$ in $\mathrm{pH} 7.4$ phosphate buffered saline (PBS) but with no serum added (Husby et al., 1975). The peripheral blood studies were carried out before surgical resection and two months (patient CL) or six months (patient GV) after surgery. Neither patient was receiving corticosteroids or azathioprine at the time of these blood studies.

SERUM IMMUNOGLOBULIN (IG) CONCENTRATIONS AND AUTOANTIBODIES

Serum concentrations of $\operatorname{IgG}, \operatorname{IgA}$, and $\operatorname{IgM}$ were determined using the Oudin tube technique as 
previously described (Wilson et al., 1967). Antibodies to smooth muscle, mitochondria, nuclei, parietal cells, and reticulin were examined by indirect immunofluorescence using unfixed frozen sections of rat liver, kidney, and stomach (Seah et al., 1971; Husby et al., 1973).

\section{Results}

\section{YMPHOCYTE DISTRIBUTIONS IN INTESTINAL} TISSUE

In control sections of histologically normal colon or ileum lymphocytes were detected by immunofluorescence between superficial epithelial cells and in the lamina propria and submucosa in both aggregated and non-aggregated distributions. The non-aggregated lymphocytes were most prominent in the mucosal lamina propria and here the proportions of $\mathbf{B}$ and $T$ cells were similar (Table 1$)$. In addition, $B$ and $T$ cells were detected in small numbers within the epithelial cell layer of normal small and large intestine. From the limited number of sections examined, it was not possible accurately to determine the proportions of $\mathrm{T}$ and $\mathrm{B}$ cells in this layer. Very few lymphocytes were detected in the deeper layers of the bowel wall and they were mostly B-cells. Immunofluorescent studies of the lymphoid aggregates in the normal ileum and colon revealed the presence of both B- and T-cells often arranged in a follicular pattern with B-cells generally located in the central regions and T-cells predominantly in peripheral areas. Within the lamina propria B-cell population, IgA was the predominant class observed $(85 \%)$. Approximately $10 \%$ of B-cells stained for IgM and $5 \%$ for IgG (Table 1).

In the tissue sections from both ileum and colon affected by Crohn's disease, immunohistological studies revealed a clear increase in lymphocytic infiltration in all layers of the bowel wall except within the superficial epithelium. In addition, an alteration in the distribution of T- and B-cells from that observed in the corresponding normal tissue was apparent. In the mucosal lamina propria from either ileum or colon a preponderance of B-cells was observed (Table 1, Figs. 1 and 2). Sixty per cent of the B-cells (many of which had the morphological features of plasma cells) were of the IgG class, $30 \%$ were of IgA class, and $10 \%$ were of IgM class. Only $25-30 \%$ of the lymphocytes in the lamina propria of intestine involved by Crohn's disease were T-cells (Table 1, Figs. 1 and 2). In the deeper layers of the bowel wall, however, the reverse was true with respect to T- and B-cell distributions. In these areas, T-cells accounted for $60-70 \%$ of the lymphocytic infiltrate, the proportion of B-cells being only $30-40 \%$ (Table 1, Figs. 1 and 2). The immunoglobulin class distribution of B-cells in the deeper layers of the bowel wall involved by Crohn's disease was similar to that observed in the lamina propria, the IgG class predominating. Very few IgE positive cells were detected and there was no apparent difference in the numbers of these cells between normal and inflamed intestinal tissue.

Numerous cells were identified in both normal intestine and that affected by Crohn's disease which bound aggregated IgG (Fig. 3). No clear quantitative difference in the number of aggregate binding cells in normal or inflamed mucosa was apparent.

\section{PERIPHERAL BLOOD B-AND T-CELLS}

The percentages and absolute numbers of $B$ - and T-cells in peripheral blood are shown in Table 2. At the time of surgery, both patients had decreased proportions and absolute numbers of T-cells, while the proportion and numbers of B-cells were within the normal range. Also, the number of cells binding aggregated IgG in patient CL did not differ from normal. Repeated determinations two or six months after surgery revealed normal T-cell proportions and numbers in both patients, and B-cell values remained normal.

\section{SERUM IMMUNOGLOBULINS AND} AUTOANTIBODIES

Serum IgM was increased in one of the patients (CL) both before and after surgery, while serum IgG and IgA levels were within normal limits both before and after surgery. All immunoglobulins were normal before and after surgery in patient GV (Table 2). Tests for antibodies to nuclei, smooth muscle,

\begin{tabular}{|c|c|c|c|c|c|c|c|}
\hline \multirow[t]{2}{*}{ Subject } & \multirow[t]{2}{*}{ Specimen } & \multicolumn{3}{|l|}{ Mucosal lamina propria } & \multicolumn{3}{|c|}{ Submucosa and muscularis } \\
\hline & & $\begin{array}{l}\text { Degree of lymphocytic } \\
\text { infiltration }\end{array}$ & $\begin{array}{l}\text { B-cells } \\
(\%)\end{array}$ & $\begin{array}{l}T \text {-cells } \\
(\%)\end{array}$ & $\begin{array}{l}\text { Degree of lymphocytic } \\
\text { infiltration }\end{array}$ & $\begin{array}{l}\text { B-cells } \\
(\%)\end{array}$ & $\begin{array}{c}T \text {-cells } \\
(\%)\end{array}$ \\
\hline $\begin{array}{l}\overline{C L} \\
\text { GV }\end{array}$ & $\begin{array}{l}\text { Crohn's colitis } \\
\text { Crohn's ileitis } \\
\text { Control colon or ileum } \ddagger\end{array}$ & $\begin{array}{l}\text { Severe } \\
\text { Severe } \\
\text { Moderate }\end{array}$ & $\begin{array}{l}70^{*} \\
75^{*} \\
50 \dagger\end{array}$ & $\begin{array}{l}30 \\
25 \\
50\end{array}$ & $\begin{array}{l}\text { Severe } \\
\text { Severe } \\
\text { Mild or absent }\end{array}$ & $\begin{array}{l}40 * \\
30 * \\
70 \dagger\end{array}$ & $\begin{array}{l}60 \\
70 \\
30\end{array}$ \\
\hline
\end{tabular}

Table 1 Lymphocyte subpopulations in resected bowel from two patients with Crohn's disease and control intestinal tissues

*IgG: IgA: IgM = 6:3:1. †IgA: IgM: IgG = 17:2:1. †Histologically normal bowel from two right hemicolectomy specimens. 


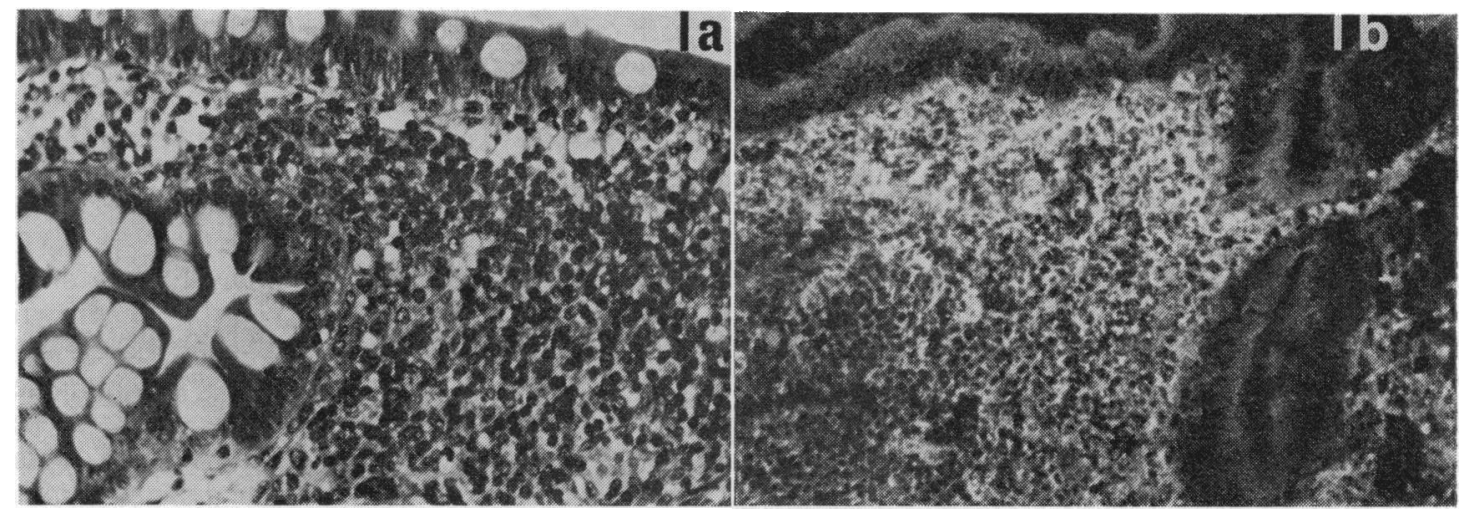

Fig. 1a Section from inflamed large intestine of patient $C L$ stained with haematoxylin and eosin showing extensive infiltration of lymphocytic cells in the mucosal lamina propria. $\times 100$ (approx.).

Fig. 1b Section from same tissue stained with Fluoresceinated anti- $F\left(a b^{\prime}\right)_{2}$ showing extensive mucosal infiltration of B-cells. $\times 160$.

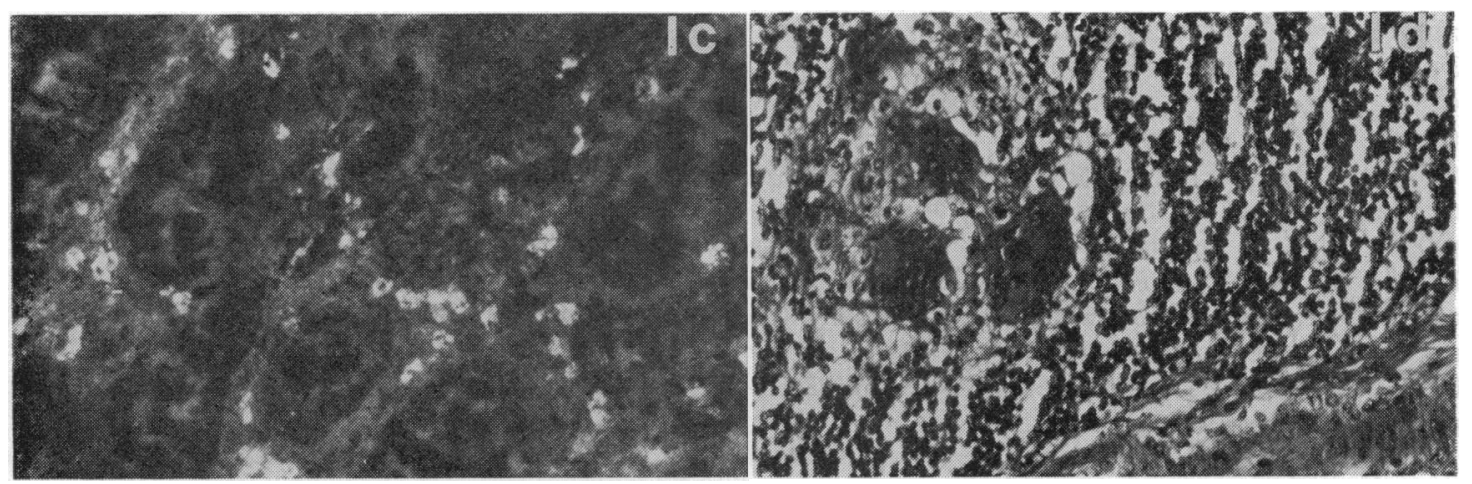

Fig. 1c Staining of section from same tissue with anti-T-cell antiserum revealed moderate mucosal infiltration of T-cells. $\times 100$ (approx.).

Fig. 1d Submucosa and muscularis of the same section as in Fig. 1a stained with haematoxylin and eosin showing severe lymphocytic infiltration and giant cells. $\times 100$ (approx.).

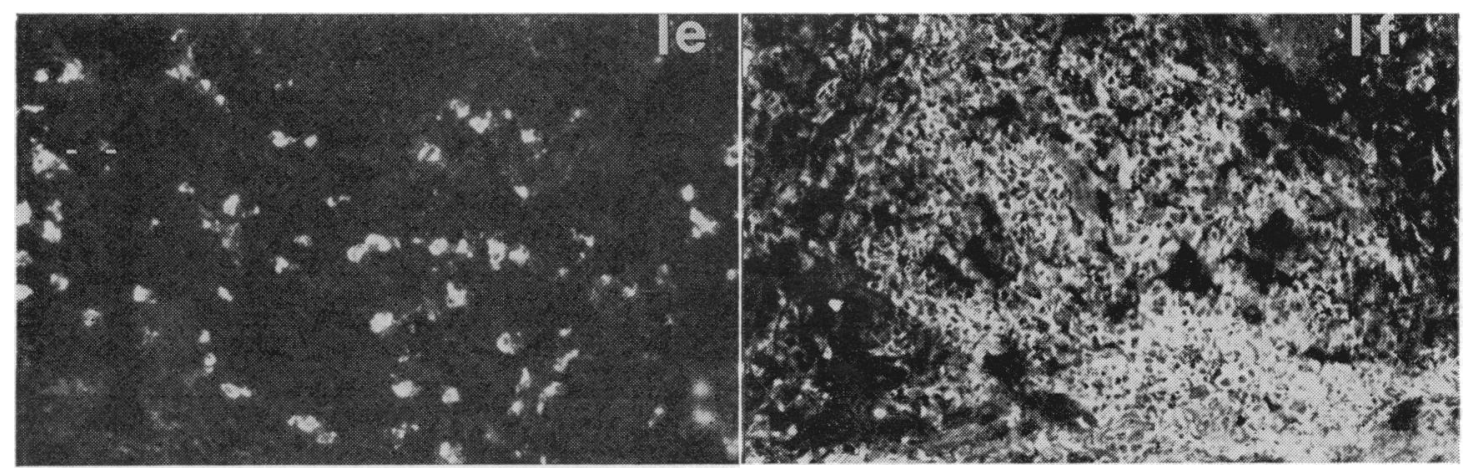

Fig. 1e Staining with anti-F(a $\left.b^{\prime}\right)_{2}$ of submucosa and muscularis of same section as in Fig. 1d revealed less numerous $B$-cells in this area of the bowel wall. $\times 100$ (approx.).

Fig. If Extensive infiltration of T-cells in submucosa and muscularis of the same section as in Fig. 1 e. $\times 100$ (approx.). 

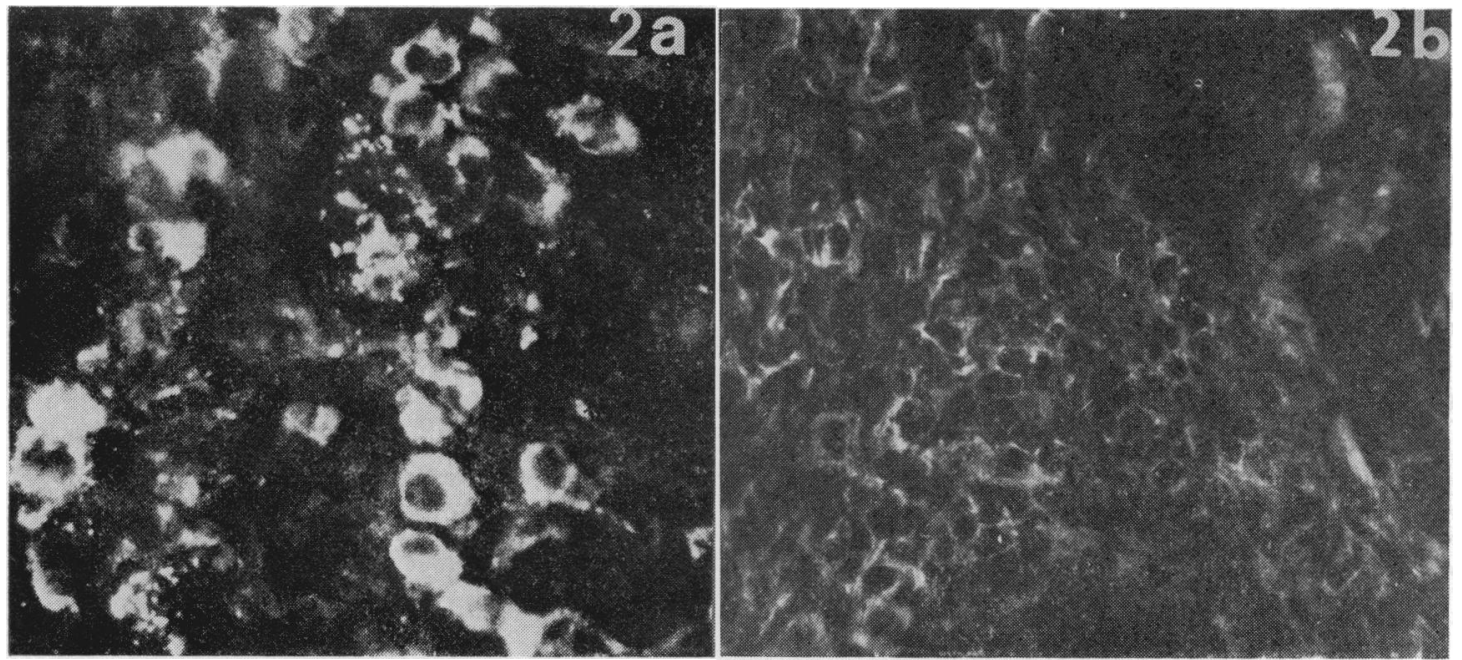

Fig. 2a Higher magnification of a less infiltrated part of the section shown in Fig. $1 b$ demonstrating B-cells with surface and cytoplasmic immunoglobulin. $\times 350$.

Fig. 2b Higher magnification of same section as in Fig. 1c showing T-cells with typical membrane fluorescence. $\times 350$.

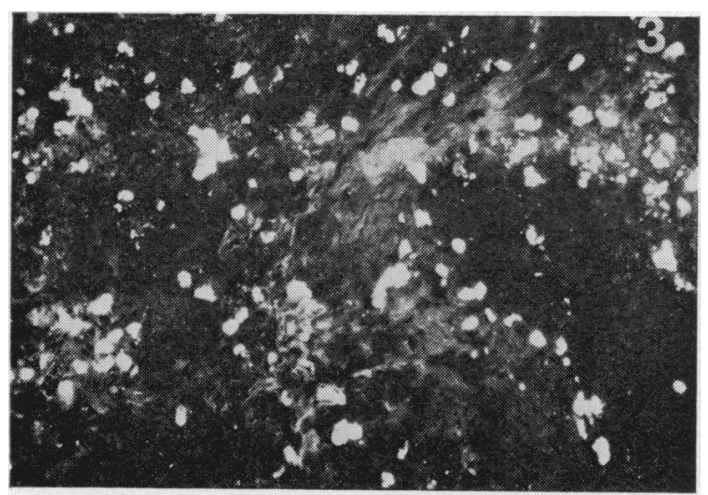

Fig. 3 Section from same intestinal tissue as Figs. 1 and 2 stained with fluorescent aggregates of $\lg G$ showing numerous cells with receptors for $F c$ in the inflammatory lesion. $\times 100$ (approx.).

mitochondria, reticulin and parietal cells were negative in both patients.

\section{Discussion}

Very little information is available regarding the immunopathology of the intestinal mucosa in Crohn's disease. An increase in lamina propria plasma cells has been reported in both involved (Persson and Danielsson, 1973; Green and Fox, 1975) and unaffected (Söltoff, 1969; Green and Fox. 1975 ) intestinal mucosa of patients with this disease.
In unaffected small bowel mucosa, IgA containing plasma cells predominate and the ratio of IgA: IgM: IgG plasma cells is similar to that observed in normal mucosa (Soltoff, 1969; Green and Fox, 1975). However, the mucosa in areas of bowel involved by Crohn's disease is characterized by a marked reduction in IgA containing plasma cells (Persson and Danielsson, 1973; Green and Fox, 1975). A corresponding increase in mucosal plasma cells containing IgG in involved areas of intestine has been reported in one study (Persson and Danielsson, 1973) but was not observed in a more recent report (Green and Fox, 1975).

The present study has utilized immunofluorescence techniques to identify $\mathrm{T}$ and $\mathrm{B}$ lymphocytes in tissue sections from normal small and large intestine and from corresponding tissue involved by Crohn's disease. A marked increase in lamina propria and submucosal lymphocytes was observed in sections from ileum or colon involved by Crohn's disease when compared with normal controls. No clear difference in the degree of intraepithelial lymphocyte infiltration between control intestine and that affected by Crohn's disease was observed in the present material. However, further studies concentrating on an examination of multiple serial sections through this layer with the markers described are needed to clarify this point. This approach may also define which lymphocyte subpopulation predominates in the intraepithelial region of human intestinal tissue. In the mucosal lamina propria of intestine involved by Crohn's disease B-cells were found to 


\begin{tabular}{|c|c|c|c|c|c|}
\hline \multirow[b]{2}{*}{$\begin{array}{l}\text { Immunoglobulin } \\
\text { concentrations }(\mathrm{mg} / \mathrm{d})\end{array}$} & \multicolumn{2}{|l|}{ Patient $C L$} & \multicolumn{2}{|l|}{ Patient GV } & \multirow{2}{*}{$\begin{array}{l}\text { Normal control values } \\
(\text { mean } \pm 1 S D)\end{array}$} \\
\hline & Preoperative & Postoperative & Preoperative & Postoperative & \\
\hline IgG & 740 & 830 & 1100 & 920 & $1278 \pm 361$ \\
\hline IgA & 240 & 320 & 330 & 390 & $282 \pm 128$ \\
\hline IgM & 320 & 300 & 110 & 115 & $135 \pm 65$ \\
\hline \multicolumn{6}{|l|}{ T-cells* } \\
\hline Percent & 42 & 66 & 19 & 59 & $64 \pm 11$ \\
\hline No. $\left(\right.$ cells $\left./ \mathrm{mm}^{3}\right)$ & 570 & 1815 & 481 & 1273 & $1629 \pm 546$ \\
\hline \multicolumn{6}{|l|}{$\begin{array}{l}\text { B-cells } \\
\text { bearing surface Ig }\end{array}$} \\
\hline Percent & 12 & 14 & 17 & 7 & $13 \pm 5$ \\
\hline No. $\left(\right.$ cells $\left./ \mathrm{mm}^{8}\right)$ & 163 & 385 & 430 & 151 & $334 \pm 202$ \\
\hline \multicolumn{6}{|l|}{ Binding aggregated IgG } \\
\hline Percent & 19 & 8 & NT & 7 & $7 \pm 4$ \\
\hline No. (cells/mm $\left./ \mathrm{mm}^{3}\right)$ & 258 & 220 & NT & 151 & $193 \pm 203$ \\
\hline
\end{tabular}

Table 2 Serum immunoglobulin levels and peripheral blood lymphocyte subpopulations in two patients with Crohn's disease before and after intestinal resection

*Cells forming sheep red blood cell rosettes.

predominate. An alteration in the normal ratio of the different immunoglobulin classes of mucosal B-cells was observed-namely, a marked reduction in cells containing or bearing $\operatorname{IgA}$ and a concomitant increase in B-cells staining for IgG. These findings confirm the earlier observations of Persson and Danielsson (1973) relating to plasma cell alterations in Crohn's mucosa. In contrast with our observations in the mucosa of involved segments of bowel wall, the deeper layers (submucosa and muscularis) contained dense infiltrates of lymphocytes in which T-cells predominated. These findings using frozen tissue sections are similar to those recorded in a recent report (Breucha and Riethmuller, 1975) which utilized lymphocyte suspensions obtained from resected ileum involved by Crohn's disease. Comparison with suspensions obtained from normal ileum revealed an increase in intestinal T-cells in Crohn's tissue as judged by proportions of lymphocytes forming spontaneous sheep red blood cell rosettes. Our observations are also supported by the study of Persson and Danielsson (1973) in which immunoglobulin containing plasma cells were found to be sparse in the submucosa of the intestine involved by Crohn's disease despite the presence of marked inflammation histologically.

The inflammatory infiltrate in Crohn's tissue was also found to contain large numbers of cells which bound aggregated IgG. Recent work (Stobo et al., 1975) has implicated a lymphocyte subpopulation with $\mathrm{Fc}$ receptors capable of binding aggregates, but lacking other characteristics of $\mathrm{T}$ or $\mathrm{B}$ cells in the in vitro cytotoxicity to cultured colon epithelial cells displayed by peripheral blood lymphocytes from patients with inflammatory bowel disease. Our demonstration of aggregate binding cells in the intestine therefore provides an important link betwe-n the in vitro phenomenon of lymphocyte cytotoxicity to cultured colon cells and the in vivo tissue destruction in Crohn's disease.

The cause of these striking lymphocyte and plasma cell abnormalities in the intestinal wall of patients with Crohn's disease is unknown. Recent evidence (Mitchell and Rees, 1970; Cave et al., 1973) implicates the existence in Crohn's intestinal homogenates of a transmissible agent and perhaps the immunopathological findings recorded here reflect the host response to such an agent. Whatever the mechanism of these changes, it seems possible that they may have relevance to the anergy and peripheral blood lymphocyte abnormalities observed in a proportion of patients with Crohn's disease. It has been previously suggested (Strober et al., 1967) that intraluminal loss of lymphocytes might contribute to the defect in cell mediated immunity in Crohn's disease, and a recent study (Douglas et al., 1975) demonstrating increased faecal loss of 51-Cr labelled lymphocytes appears to be the first directly to document such a phenomenon in this disease.

These observations, together with the present findings of a reversion of peripheral blood T-cell numbers to normal after bowel resection, are most consistent with the view that many of the cellular immune abnormalities reported with varying frequency in Crohn's disease are secondary to immune intestinal sequestration and/or loss of lymphocytes. However, the present findings do not entirely rule out the existence of a more subtle primary abnormality of T-cell function in Crohn's disease.

\section{References}

Asquith, P., Kraft, S. C., and Rothberg, R. M. (1973). Lymphocyte responses to nonspecific mitogens in inflammatory bowel disease. Gastroenterology, 65, 1-7. 
Bird, A. G., and Britton, S. (1974). No evidence for decreased lymphocyte reactivity in Crohn's disease. Gastroenterology, 67, 926-932.

Bolton, P. M., James, S. L., Newcombe, R. G., Whitehead, R. H., and Hughes, L. E. (1974). The immune competence of patients with inflammatory bowel disease. Gut, 15, 213-219.

Breucha, G., and Riethmüller, G. (1975). Intestinal lymphocytes in Crohn's disease. Lancet, 1, 976.

Cave, D. R., Mitchell, D. N., Kane, S. P., and Brooke, B. N. (1973). Further animal evidence of a transmissible agent in Crohn's disease. Lancet, 2, 1120-1122.

Dickler, H. B., and Kunkel, H. G. (1972). Interaction of aggregated $\gamma$-globulin with B lymphocytes. Journal of Experimental Medicine, 136, 191-196.

Douglas, A. P., Weetman, A. P., and Haggith, J. (1975). Enteric loss of lymphocytes in celiac disease and in Crohn's disease. Gastroenterology, 68, 1056.

Fletcher, J., and Hinton, J. M. (1967). Tuberculin sensitivity in Crohn's disease: a controlled study. Lancet, 2, 753-754.

Green, F. H. Y., and Fox, H. (1975). The distribution of mucosal antibodies in the bowel of patients with Crohn's disease. Gut, 16, 125-131.

Guillou, P. J., Brennan, T. G., and Giles, G. R. (1973). Lymphocyte transformation in the mesenteric lymph nodes of patients with Crohn's disease. Gut, 14, 20-24.

Husby, G., Blomhoff, J. P., Skrede, S., Elgjo, K., and Gjone, E. (1973). Detection of immunoglobulin in paraffinembedded liver biopsies. Scandinavian Journal of Gastroenterology, 8, 621-629.

Husby, G., Strickland, R. G., Caldwell, J. L., and Williams, R. C., Jr (1975). Localization of T- and B-cells and alphageto-protein in hepatic biopsies from patients with liver disease. Journal of Clinical Investigation. 56, 1198-1209.

Jones, J. V., Housley, J., Ashurst, P. M., and Hawkins, C. F. (1969). Development of delayed hypersensitivity to dinitrochlorobenzene in patients with Crohn's disease. Gut, $10,52-56$.

Mitchell, D. N., and Rees, R. J. W. (1970). Agent transmissible from Crohn's disease tissue. Lancet, 2, 168-171.

Parent, K., Barrett, J., and Wilson, I. D. (1971). Investigation of the pathogenic mechanisms in regional enteritis with in vitro lymphocyte cultures. Gastroenterology, 61, 431-439.

Persson, S., and Danielsson, D. (1973). Studies on Crohn's disease II. Immunoglobulin-containing cells in the terminal ileum. Acta Chirurgica Scandinavica, 139, 735-738.

Richens, E. R., Williams, M. J., Gough, K. R., and Ancill, R. J. (1974). Mixed-lymphocyte reaction as a measure of immunological competence of lymphocytes from patients with Crohn's disease. Gut, 15, 24-28.

Röpke, C. (1972). Lymphocyte transformation and delayed hypersensitivity in Crohn's disease. Scandinavian Journal of Gastroenterology, 7, 671-677.

Sachar, D. B., Taub, R. N., Brown, S. M., Present, D. H., Korelitz, B. I., and Janowitz, H. D. (1973). Impaired lymphocyte responsiveness in inflammatory bowel disease. Gastroenterology, 64, 203-209.

Seah, P. P., Fry, L., Hoffbrand, A. V., and Holborow, E. J. (1971). Tissue antibodies in dermatitis herpetiformis and adult coeliac disease. Lancet, 1, 834-836.

Söltoff, J. (1969). Immunoglobulin-containing cells in normal jejunal mucosa and in ulcerative colitis and regional enteritis. Scandinavian Journal of Gastroenterology, 4, 353-360.

Stobo, J. D., Tomasi, T. B., Huizenga, K. A., Spencer, R. J., and Shorter, R. G. (1975). Idiopathic colitis, surface receptors of the mononuclear cell required for in vitro lysis of colon epithelium. Gastroenterology, 68, 992.

Strickland, R. G., Korsmeyer, S., Soltis, R. D., Wilson, I. D., and Williams, R. C., Jr (1974). Peripheral blood T and B cells in chronic inflammatory bowel disease. Gastroenterology, 67, 569-577.

Strober, W., Wochner, R. D., Carbone, P. P., and Waldmann, T. A. (1967). Intestinal lymphangiectasia: a proteinlosing enteropathy with hypogammaglobulinemia,lymphocytopenia and impaired homograft rejection. Journal of Clinical Investigation, 46, 1643-1656.

Williams, W. J. (1965). A study of Crohn's syndrome using tissue extracts and the Kveim and Mantoux tests. Gut, 6, 503-505.

Wilson, I. D., Williams, R. C., Jr, Tobian, L., Jr (1967). Renal tubular acidosis. Three cases with immunoglobulin abnormalities in the patients and their kindreds. American Journal of Medicine, 43, 356-370.

Winchester, R. J., Fu, S. M., Hoffman, T., and Kunkel, H. G. (1975). IgG on lymphocyte surfaces: technical problems and the significance of a third cell population. Journal of Immunology, 114, 1210-1212. 